\title{
MORPHOLOGICAL STUDY OF INTESTINAL POLYPS WITH CLINICOPATHOLOGICAL CORRELATION - 2 YEARS OBSERVATIONAL STUDY AT A TERTIARY CARE CENTRE OF SOUTH INDIA
}

\author{
Shiny Padinjarayil Manakkad1, Rema Priyadarshini², Bindu V3
}

${ }^{1}$ Assistant Professor, Department of Pathology, Government Medical College, Kozhikode. ${ }^{2}$ Additional Professor, Department of Pathology, Government Medical College, Alappuzha. ${ }^{3}$ Assistant Professor, Department of Social and Preventive Medicine, Government Medical College, Kozhikode.

\begin{abstract}
BACKGROUND

Polyps of the intestine are common specimens and do not have symptoms unless they cause obstruction or bleed. ${ }^{1}$ There are many types of intestinal polyps. Among all polyps, most frequently occurring are adenomatous polyps. Adenomas are considered precursor lesions to invasive carcinoma. Colorectal cancer stands second to lung cancer as the most common cause of cancer mortality. The basic aim of management of patients with adenomatous polyps in the large bowel remains to prevent the development of cancer by detection and removal of precancerous lesions.

The objective of this study is to classify intestinal polyps and identify prevalence of each morphologic type. To study the gross and histopathological features and to correlate with clinical data.
\end{abstract}

\section{MATERIALS AND METHODS}

This prospective study was conducted for a period of two years in Department of Pathology. The material included 46 intestinal resections, 61 polypectomies and 53 mucosal biopsies. Collected data entered in MS-Excel and analysed using SPSS-16.

\section{RESULTS}

160 intestinal polyps were studied during a period of two years. Neoplastic polyps (79\%) were common than non-neoplastic polyps (21\%). Among the neoplastic polyps, adenomatous polyps (81\%) constitute majority of cases. Among the non-neoplastic polyps, juvenile polyps were common. Majority of cases of neoplastic polyps (55.6\%) were in older age group, while majority of nonneoplastic polyps (73.5\%) in younger age group. Male predominance was seen. Majority of polyps (86.8\%) were in large intestine and most of them were pedunculated polyps (66.25\%). Most frequent presenting complaints were bleeding per rectum. Among larger polyps, $91.5 \%$ of cases were neoplastic.

\section{CONCLUSION}

This study summarises various types of intestinal polyps. Adenomatous polyp presented the majority type and showed an increase in incidence in older age group. This shows that risk factor for development of adenomatous polyps and hence colorectal malignancy increases as age advances. Majority of adenomatous polyps were in distal part of large intestine. Distal predominance of adenomatous polyps support adenoma-carcinoma hypothesis. Adenomas with increased size $(>=1 \mathrm{~cm})$ have a much higher malignant potential. The main purpose of screening is to detect such lesions before they become malignant. In younger children, most common polyps of the colon were juvenile polyp which is a non-neoplastic polyp.

\section{KEYWORDS}

Neoplastic Polyps, Non-Neoplastic Polyps, Adenomatous Polyps, Malignant Potential.

HOW TO CITE THIS ARTICLE: Manakkad SP, Priyadarshini R, Bindu V. Morphological study of intestinal polyps with clinicopathological correlation - 2 years observational study at a tertiary care centre of South India. J. Evolution Med. Dent. Sci. 2016;5(102):7491-7498, DOI: 10.14260/jemds/2016/1696

\section{BACKGROUND}

Polyps of the intestine are one of the common specimens for the practicing pathologists. Intestinal polyps are mucosal projections from the epithelial lining into the lumen of any part of intestine.

These polyps vary in size, shape and histopathology. They usually do not cause symptoms unless they cause obstruction or bleed. There are many types of intestinal polyps and accurate histological assessment is important for accurate

Financial or Other, Competing Interest: None.

Submission 15-11-2016, Peer Review 07-12-2016,

Acceptance 15-12-2016, Published 22-12-2016.

Corresponding Author:

Dr. Shiny Padinjarayil Manakkad

Vinodini Vihar,

(PO)-Kolathara, Calicut.

E-mail: shinypath77@gmail.com

DOI: 10.14260/jemds/2016/1696 diagnosis and appropriate management of the patients. Therefore, all polyps must be excised to achieve a final diagnosis. Polyps are classified into non-neoplastic and neoplastic polyps. Among all polyps neoplastic polyps are common, of which most frequently occurring are adenomatous polyps. ${ }^{1}$ Non-neoplastic polyps or tumour-like lesions were previously thought to have no malignant potential. These views of the totally harmless nature of nonneoplastic polyps are no longer true. Juvenile polyposis syndrome and Peutz Jeghers polyposis syndrome have malignant potential through adenomatous change. Among all polyps, most frequently occurring are adenomatous polyps..$^{2,3}$

Precursor lesions to invasive carcinoma are adenomatous polyps. Adenomas more than $10 \mathrm{~mm}$ are called adenomas with advanced pathology. Risk of malignancy increases with increase in size. The main aim of diagnosis of adenomatous polyps is to remove those lesions and prevent the development of cancer. ${ }^{4}$ So effective screening strategies are 
very important. So present study is aimed to classify intestinal polyps, to know proportion of each morphological type, to correlate age, sex, site of clinical features and histology of the polyps.

\section{MATERIALS AND METHODS}

The study was conducted in Department of Pathology. The material included 46 intestinal resections (28.8\%), 61 polypectomy specimens (38.1\%) and 53 mucosal biopsies (33.1\%). The study was approved by Ethics Committee of the institution. Specimens were fixed in $10 \%$ formalin, processed and sections were stained with haematoxylin and eosin. If necessary, special stains (trichrome stain) and immunohistochemical studies (LCA, CD20 and CD3) were done.

All statistical analysis was done with SPSS-16. Chi square value and $\mathrm{P}$ value were calculated. $\mathrm{P}$ value $<0.05$ was significant.

\section{RESULTS}

During a period of two years, one hundred and sixty cases of intestinal polyps were studied. Neoplastic polyps (126 cases) were found to be common than non-neoplastic polyps (34 cases).

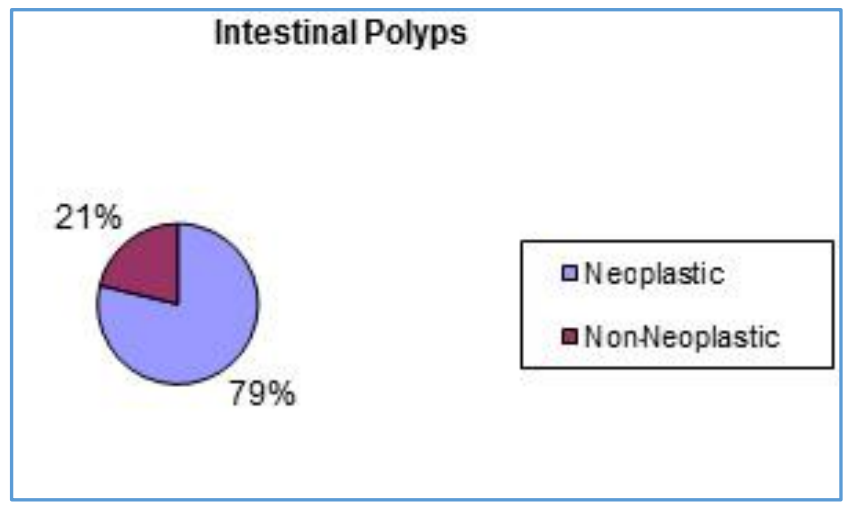

Figure 1. Types of Intestinal Polyps Neoplastic vs. Non-Neoplastic

\section{Age}

The age of patients ranged from 2 - 85 years. Most frequent age group affected in our study was $40-49$ years (18.1\%). Majority of cases of neoplastic polyps were in older age group (51 and above), while majority of non-neoplastic polyps in younger age group ( $<30$ yrs.). Mean age was 47.14 with standard deviation of 22.13. Among adenomatous polyps, majority of cases were in older age group. Majority of cases of juvenile polyps were in first decade. Distribution of different types of polyps based on age groups are shown in Table 1 .

\begin{tabular}{|c|c|c|c|c|c|c|}
\hline Age & \multicolumn{7}{|c|}{ Type of Polyp } \\
\hline & Based on Clinical Behaviour & \multicolumn{3}{c|}{ Sub-Classified Based on Histopathology } \\
\hline & $\begin{array}{c}\text { Neoplastic } \\
(\mathrm{N}=126)\end{array}$ & $\begin{array}{c}\text { Non-Neoplastic } \\
(\mathrm{N}=34)\end{array}$ & $\begin{array}{c}\text { Adenomatous } \\
(\mathrm{N}=102)\end{array}$ & $\begin{array}{c}\text { Non-Adenomatous } \\
\text { Neoplastic Polyps (N=24) }\end{array}$ & $\begin{array}{c}\text { Juvenile } \\
(\mathrm{N}=25)\end{array}$ & $\begin{array}{c}\text { Others* } \\
(\mathrm{N}=9)\end{array}$ \\
\hline $0-29(\mathrm{n}=33)$ & $8(24.2 \%)$ & $25(75.8 \%)$ & $5(15.2 \%)$ & $3(9.1 \%)$ & $24(72.7 \%)$ & $1(3 \%)$ \\
\hline $30-50(\mathrm{n}=52)$ & $48(92.3 \%)$ & $4(7.7 \%)$ & $35(67.3 \%)$ & $13(25 \%)$ & $1(1.9 \%)$ & $3(5.8 \%)$ \\
\hline 51 and above $(\mathrm{n}=75)$ & $70(93.3 \%)$ & $5(6.7 \%)$ & $62(82.7 \%)$ & $8(10.7 \%)$ & 0 & $5(6.7 \%)$ \\
\hline \multicolumn{3}{|c|}{ Table 1. Age Distribution of Intestinal Polyps } \\
\hline \multicolumn{3}{|c|}{$0.000(<0.05)$} \\
\hline
\end{tabular}

*Others - non-neoplastic polyps like Hyperplastic polyp, Peutz-Jegher polyp, inflammatory myoglandular polyp and Angiogenic polyp.

\section{Sex}

Male predominance was seen in both neoplastic and non-neoplastic polyps. In both males and females, the incidence of adenomatous polyps increases with age. Distribution of different types of polyps based on gender are shown in Table 2 .

\begin{tabular}{|c|c|c|c|c|c|c|}
\hline Sex & \multicolumn{7}{|c|}{ Type of Polyp } \\
\hline & Based on Clinical Behaviour & \multicolumn{3}{c|}{ Sub-Classified Based on Histopathology } \\
\hline & $\begin{array}{c}\text { Neoplastic } \\
(\mathrm{N}=126)\end{array}$ & $\begin{array}{c}\text { Non-Neoplastic } \\
(\mathrm{N}=34)\end{array}$ & $\begin{array}{c}\text { Adenomatous } \\
(\mathrm{N}=102)\end{array}$ & $\begin{array}{c}\text { Non-Adenomatous } \\
\text { Neoplastic Polyps }(\mathrm{N}=24)\end{array}$ & $\begin{array}{c}\text { Juvenile } \\
(\mathrm{N}=25)\end{array}$ & $\begin{array}{c}\text { Others } \\
(\mathrm{N}=9)\end{array}$ \\
\hline $\mathrm{M}(\mathrm{n}=93)$ & $71(76.3 \%)$ & $22(23.7 \%)$ & $61(65.6 \%)$ & $10(10.8 \%)$ & $18(19.4 \%)$ & $4(4.3 \%)$ \\
\hline $\mathrm{F}(\mathrm{n}=67)$ & $55(82.1 \%)$ & $12(17.9 \%)$ & $41(61.2 \%)$ & $14(20.9 \%)$ & $7(10.4 \%)$ & $5(7.5 \%)$ \\
\hline \multicolumn{7}{|c|}{ Table 2. Sex Distribution in Intestinal Polyps } \\
\hline
\end{tabular}

\section{Clinical Features}

Most frequent presenting complaint was bleeding per rectum (49.37\%), which was also the case with adenomatous polyps and adenocarcinoma. Distributions of clinical features of different types of polyps are shown in Table 3. 


\begin{tabular}{|c|c|c|c|c|c|c|}
\hline \multirow[t]{3}{*}{ Clinical Features } & \multicolumn{6}{|c|}{ Type of Polyp } \\
\hline & \multicolumn{2}{|c|}{ Based on Clinical Behaviour } & \multicolumn{4}{|c|}{ Sub-Classified Based on Histopathology } \\
\hline & $\begin{array}{l}\text { Neoplastic } \\
(\mathrm{N}=126)\end{array}$ & $\begin{array}{c}\text { Non-neoplastic } \\
(\mathrm{N}=34)\end{array}$ & $\begin{array}{l}\text { Adenomatous } \\
\qquad(\mathrm{N}=102)\end{array}$ & $\begin{array}{c}\text { Non- } \\
\text { Adenomatous } \\
\text { Neoplastic } \\
\text { Polyps }(\mathrm{N}=24)\end{array}$ & $\begin{array}{l}\text { Juvenile } \\
(\mathrm{N}=25)\end{array}$ & $\begin{array}{l}\text { Others } \\
(\mathrm{N}=9)\end{array}$ \\
\hline Bleeding per Rectum $(n=78)$ & $55(70.5 \%)$ & $23(29.5 \%)$ & $47(60.3 \%)$ & $8(10.3 \%)$ & $21(26.9 \%)$ & $2(2.6 \%)$ \\
\hline Abdominal Mass $(\mathrm{n}=2)$ & $2(100 \%)$ & 0 & $2(100 \%)$ & 0 & 0 & 0 \\
\hline Abdominal Pain $(\mathrm{n}=32)$ & $29(90.6 \%)$ & $3(9.4 \%)$ & $15(46.9 \%)$ & $14(43.8 \%)$ & 0 & $3(9.4 \%)$ \\
\hline Mass per Rectum $(n=2)$ & $2(100 \%)$ & 0 & $2(100 \%)$ & 0 & 0 & 0 \\
\hline Mucus per Rectum $(n=6)$ & $5(83.3 \%)$ & $1(16.7 \%)$ & $4(66.7 \%)$ & $1(16.7 \%)$ & $1(16.7 \%)$ & 0 \\
\hline Asymptomatic $(\mathrm{n}=40)$ & $33(82.5 \%)$ & $7(17.5 \%)$ & $32(80.0 \%)$ & $1(2.5 \%)$ & $3(7.5 \%)$ & $4(10 \%)$ \\
\hline \multicolumn{3}{|c|}{ P value -0.196} & \multicolumn{4}{|c|}{ P value $-0.000(<0.05)$} \\
\hline
\end{tabular}

\section{Site of Involvement}

Majority of polyps (86.8\%) were present in large intestine. All the adenomatous polyps were seen in large intestine (100\%), which was statistically significant (P value - <.05). They displayed left-sided predominance (85.5\%); 74\% of adenomatous polyps in rectum and $85.7 \%$ of adenomatous polyps in anal canal showed larger size $(>1 \mathrm{~cm}$ ), which was statistically significant (p value - .03). Only $6 \%$ of polyps were seen in right-sided colon, of which $70 \%$ of cases were adenomatous polyps. Among the adenomatous polyps in right-sided colon, $85.7 \%$ of the cases were in older age group. Majority of juvenile polyps were seen in rectum (88\%).

Distributions of sites of different types of polyps are shown in Table 4.

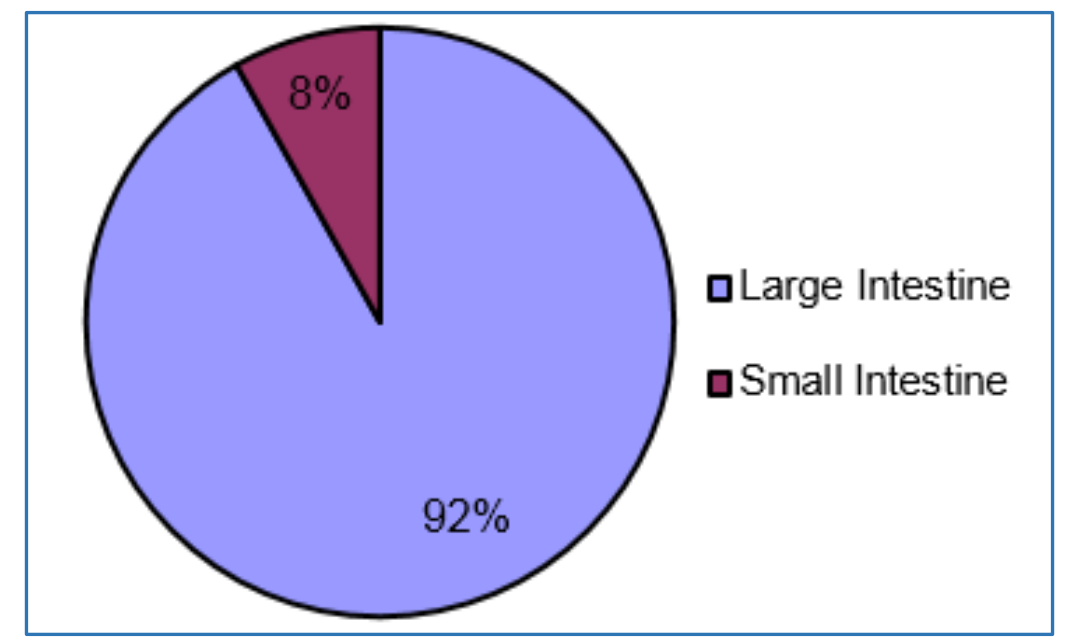

Figure 2. Distribution of Polyps by Site

\begin{tabular}{|c|c|c|c|c|c|c|}
\hline \multirow{3}{*}{ Site } & \multicolumn{6}{|c|}{ Type of Polyp } \\
\hline & \multicolumn{2}{|c|}{$\begin{array}{c}\text { (Based on Clinical } \\
\text { Behaviour) }\end{array}$} & \multicolumn{4}{|c|}{ (Sub-Classified Based on Histopathology) } \\
\hline & $\begin{array}{l}\text { Neoplastic } \\
(\mathrm{N}=126)\end{array}$ & $\begin{array}{c}\text { Non-Neoplastic } \\
\qquad(\mathrm{N}=34)\end{array}$ & $\begin{array}{l}\text { Adenomatous } \\
\qquad(\mathrm{N}=102)\end{array}$ & $\begin{array}{c}\text { Non-Adenomatous } \\
\text { Neoplastic Polyps } \\
(\mathrm{N}=24)\end{array}$ & $\begin{array}{l}\text { Juvenile } \\
(\mathrm{N}=25)\end{array}$ & $\begin{array}{l}\text { Others } \\
(\mathrm{N}=9)\end{array}$ \\
\hline Rectum $(n=67)$ & $44(65.7 \%)$ & $23(34.3 \%)$ & $39(58.2 \%)$ & $5(7.5 \%)$ & $22(32.8 \%)$ & $1(1.5 \%)$ \\
\hline Descending Colon $(n=54)$ & $47(87.0 \%)$ & $7(13 \%)$ & $41(75.9 \%)$ & $6(11.1 \%)$ & $3(5.6 \%)$ & $4(7.4 \%)$ \\
\hline Ascending Colon $(\mathrm{n}=10)$ & $10(100 \%)$ & $0(0 \%)$ & $7(70 \%)$ & $3(30 \%)$ & 0 & 0 \\
\hline Small Intestine $(\mathrm{n}=13)$ & $10(76.9 \%)$ & $3(23.1 \%)$ & 0 & $10(76.9 \%)$ & 0 & $3(23.1 \%)$ \\
\hline Diffuse $(n=8)$ & $8(100 \%)$ & $0(0 \%)$ & $8(100 \%)$ & 0 & 0 & 0 \\
\hline Anal Canal $(\mathrm{n}=8)$ & $7(87.5 \%)$ & $1(12.5 \%)$ & $7(87.5 \%)$ & 0 & 0 & $1(12.5 \%)$ \\
\hline \multicolumn{3}{|c|}{ P value $-0.014(<0.05)$} & \multicolumn{4}{|c|}{ P value $-0.000(<0.05)$} \\
\hline
\end{tabular}

\section{Gross Feature}

Twenty nine cases (17.6\%) presented with multiple polyps. Both the neoplastic and non-neoplastic polyps were presented as single polyps.

Distribution of gross features (No. of polyps) of different types of polyps are shown in Table 5. 


\begin{tabular}{|c|c|c|c|c|c|c|}
\hline \multirow[t]{3}{*}{ No. of Polyp } & \multicolumn{6}{|c|}{ Type of Polyp } \\
\hline & \multicolumn{2}{|c|}{ Based on Clinical Behaviour } & \multicolumn{4}{|c|}{ Sub-Classified Based on Histopathology } \\
\hline & $\begin{array}{l}\text { Neoplastic } \\
(\mathrm{N}=126)\end{array}$ & $\begin{array}{c}\text { Non-Neoplastic } \\
(\mathrm{N}=34)\end{array}$ & $\begin{array}{l}\text { Adenomatous } \\
\quad(\mathrm{N}=102)\end{array}$ & $\begin{array}{c}\text { Non-Adenomatous } \\
\text { Neoplastic Polyps }(\mathrm{N}=24)\end{array}$ & $\begin{array}{c}\text { Juvenile } \\
(\mathrm{N}=25)\end{array}$ & $\begin{array}{l}\text { Others } \\
(\mathrm{N}=9)\end{array}$ \\
\hline Single $(\mathrm{n}=131)$ & $100(76.3 \%)$ & $31(23.7 \%)$ & $79(60.3 \%)$ & $21(16 \%)$ & $24(18.3 \%)$ & $7(5.3 \%)$ \\
\hline Multiple $(n=29)$ & $26(89.7 \%)$ & $3(10.3 \%)$ & $23(79.3 \%)$ & $3(10.3 \%)$ & $1(3.4 \%)$ & $2(6.9 \%)$ \\
\hline \multicolumn{3}{|c|}{ P value -0.086} & \multicolumn{4}{|c|}{ P value -0.150} \\
\hline \multicolumn{7}{|c|}{ Table 5. Number of Polyps } \\
\hline
\end{tabular}

\section{Sessile/Pedunculated}

Majority of the non-neoplastic polyps (94.1\%) and majority of juvenile polyps (96\%) were pedunculated, which was statistically significant.

Distributions of gross features of different types of polyps are shown in Table 6.

\begin{tabular}{|c|c|c|c|c|c|c|}
\hline Gross Morphology & \multicolumn{5}{|c|}{ Type of Polyp } \\
\hline & Based on Clinical Behaviour & \multicolumn{3}{c|}{ Sub-Classified Based on Histopathology } \\
\hline & $\begin{array}{c}\text { Neoplastic } \\
(\mathrm{N}=126)\end{array}$ & $\begin{array}{c}\text { Non-Neoplastic } \\
(\mathrm{N}=34)\end{array}$ & $\begin{array}{c}\text { Adenomatous } \\
(\mathrm{N}=102)\end{array}$ & $\begin{array}{c}\text { Non-Adenomatous } \\
\text { Neoplastic Polyps } \\
(\mathrm{N}=24)\end{array}$ & $\begin{array}{c}\text { Juvenile } \\
(\mathrm{N}=25)\end{array}$ & $\begin{array}{c}\text { Others } \\
(\mathrm{N}=9)\end{array}$ \\
\hline Sessile (n = 54) & $52(96.3 \%)$ & $2(3.7 \%)$ & $39(72.2 \%)$ & $13(24.1 \%)$ & $1(1.9 \%)$ & $1(1.9 \%)$ \\
\hline Pedunculated (n = 106) & $74(69.8 \%)$ & $32(30.2 \%)$ & $63(59.4 \%)$ & $11(10.4 \%)$ & $24(22.6 \%)$ & $8(7.5 \%)$ \\
\hline \multicolumn{3}{|c|}{ Table 6. Gross Morphology of Intestinal Polyps } \\
\hline
\end{tabular}

\section{Size}

Among larger polyps $91.5 \%$ were neoplastic, while only $8.5 \%$ were non-neoplastic. This finding showed statistical significance; $61.8 \%$ of adenomatous polyps were of size $>=1 \mathrm{~cm}$, which was statistically significant ( $\mathrm{P}$ value $=0.01$ ); $78 \%$ of adenomatous polyps in females were of larger size, while in males both smaller and larger polyps were in equal proportion ( $\mathrm{P}$ value $=0.005)$. Distributions of size of different types of polyps are shown in Table 7.

\begin{tabular}{|c|c|c|c|c|c|c|}
\hline \multirow[t]{3}{*}{ Size $(\mathrm{cm})$} & \multicolumn{6}{|c|}{ Type of Polyp } \\
\hline & \multicolumn{2}{|c|}{ Based on Clinical Behaviour } & \multicolumn{4}{|c|}{ Sub-Classified based on Histopathology } \\
\hline & $\begin{array}{l}\text { Neoplastic } \\
(\mathrm{N}=126)\end{array}$ & $\begin{array}{c}\text { Non-Neoplastic } \\
(\mathrm{N}=34)\end{array}$ & $\begin{array}{l}\text { Adenomatous } \\
\quad(\mathrm{N}=102)\end{array}$ & $\begin{array}{l}\text { Non-Adenomatous Neoplastic } \\
\text { Polyps }(\mathrm{N}=24)\end{array}$ & $\begin{array}{c}\text { Juvenile } \\
(\mathrm{N}=25)\end{array}$ & $\begin{array}{l}\text { Others } \\
(\mathrm{N}=9)\end{array}$ \\
\hline$<1(\mathrm{n}=49)$ & $40(81.6 \%)$ & $9(18.4 \%)$ & $39(79.6 \%)$ & $1(2 \%)$ & $6(12.2 \%)$ & $3(6.1 \%)$ \\
\hline $1-2(n=52)$ & $32(61.5 \%)$ & $20(38.5 \%)$ & $30(57.7 \%)$ & $2(3.8 \%)$ & $16(30.8 \%)$ & $4(7.7 \%)$ \\
\hline$>2(\mathrm{n}=59)$ & $54(91.5 \%)$ & $5(8.5 \%)$ & $33(55.9 \%)$ & $21(35.6 \%)$ & $3(5.1 \%)$ & $2(3.4 \%)$ \\
\hline \multicolumn{3}{|c|}{ P value $-0.000(<0.05)$} & \multicolumn{4}{|c|}{ P value $-0.000(<0.05)$} \\
\hline & & & ble 7. Size Di & ion of Polyps & & \\
\hline
\end{tabular}

\section{Histopathology}

Among the neoplastic polyps, epithelial polyps (105 cases, $65.63 \%$ ) accounted for maximum number of cases with adenomatous polyps constituting 102 (63.76\%) cases. Lipomatous polyps were mostly seen in the fifth decade in leftsided colon with almost equal incidence in males and females. Inflammatory fibroid polyps were seen in the third, fifth and sixth decade, and most common site being the small intestine. There was one case each of leiomyomatous polyp and gastrointestinal stromal tumour, which were located in the small intestine.

There were three cases of Non-Hodgkin Lymphoma in the second, sixth and eighth decade. Two of them were in the large intestine and one in the small intestine; 2 cases of NonHodgkin lymphoma were of MALT type category and one of diffuse large B cell lymphoma.

Among the non-neoplastic polyps, juvenile polyps were the most common. There were one case each in inflammatory myoglandular polyp and angiogenic polyp. Inflammatory myoglandular polyp was in the age group $60-69$ yrs. and located in large intestine angiogenic polyp in 30 - 39 yrs. and located in small intestine.

Histopathologies of different types of polyps are shown in Table 8.

\begin{tabular}{|c|c|c|}
\hline Type of Polyp & Number & Percentage \\
\hline Neoplastic & $\mathbf{1 2 6}$ & $\mathbf{7 8 . 7 5}$ \\
\hline Epithelial & $\mathbf{1 0 5}$ & $\mathbf{6 5 . 6 3}$ \\
\hline Adenomatous Polyp & 102 & 63.76 \\
\hline Adenocarcinoma & 3 & 1.88 \\
\hline Mesenchymal & $\mathbf{2 1}$ & $\mathbf{1 3 . 1 3}$ \\
\hline Inflammatory Fibroid Polyp & 7 & 4.38 \\
\hline Lipomatous Polyp & 9 & 5.63 \\
\hline Leiomyomatous Polyp & 1 & 0.63 \\
\hline Non-Hodgkin Lymphoma & 3 & 1.88 \\
\hline Gastrointestinal Stromal Tumour & 1 & 0.63 \\
\hline Non-Neoplastic & $\mathbf{3 4}$ & $\mathbf{2 1 . 2 5}$ \\
\hline
\end{tabular}




\begin{tabular}{|c|c|c|}
\hline Juvenile Polyp & 25 & 15.63 \\
\hline Hyperplastic Polyp & 2 & 1.25 \\
\hline Peutz-Jeghers Polyp & 4 & 2.5 \\
\hline Inflammatory Myoglandular Polyp & 1 & 0.63 \\
\hline Angiogenic Polyp & 1 & 0.63 \\
\hline Fibroepithelial Polyp & 1 & 0.63 \\
\hline Total & $\mathbf{1 6 0}$ & $\mathbf{1 0 0}$ \\
\hline Table 8. Histopathology of Different Types of Polyps \\
\hline
\end{tabular}

Photomicrographic pictures of intestinal polyps are shown below in Figures 3 - 9.

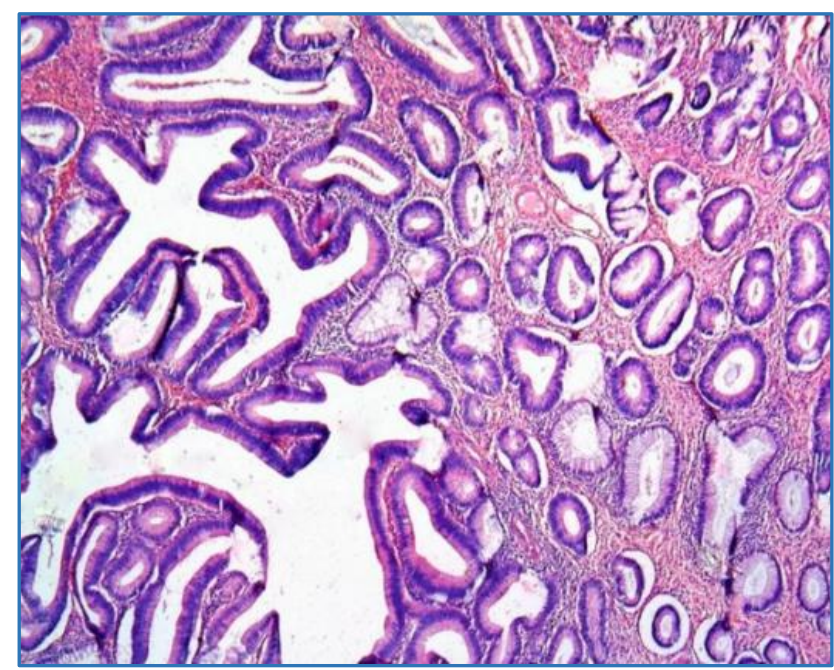

Figure 3. Adenomatous Polyp (H \& E x 40)

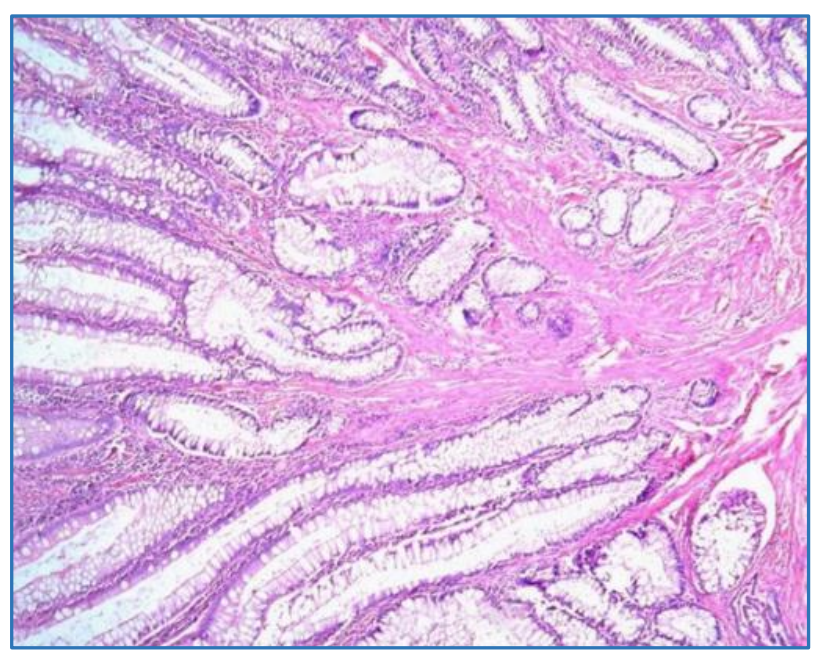

Figure 4. Inflammatory Myoglandular Polyp: Showing Inflammation, Smooth Muscle Proliferation and Hyperplastic Glands (H \& E X40)

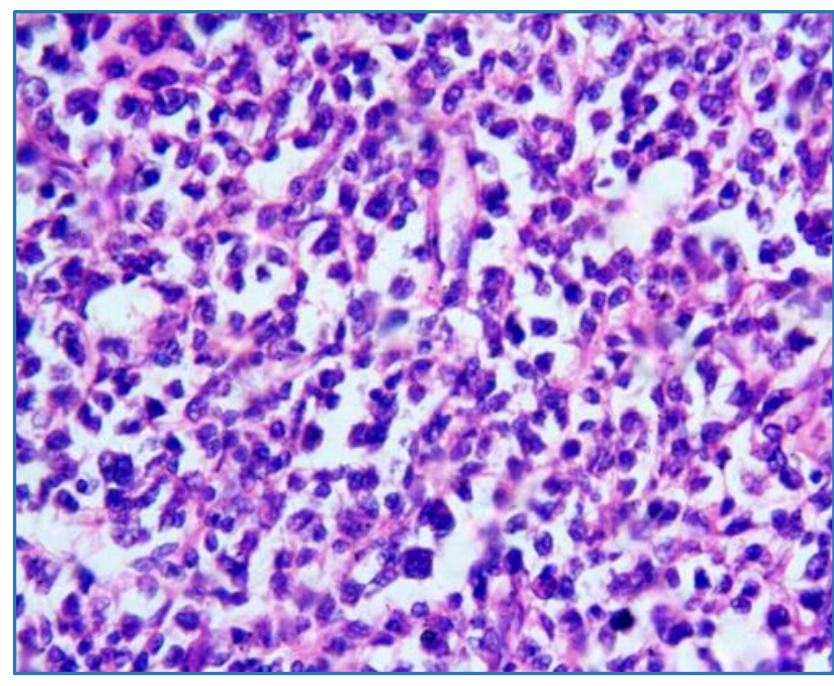

Figure 5. Non-Hodgkin's Lymphoma (H \& E x400)

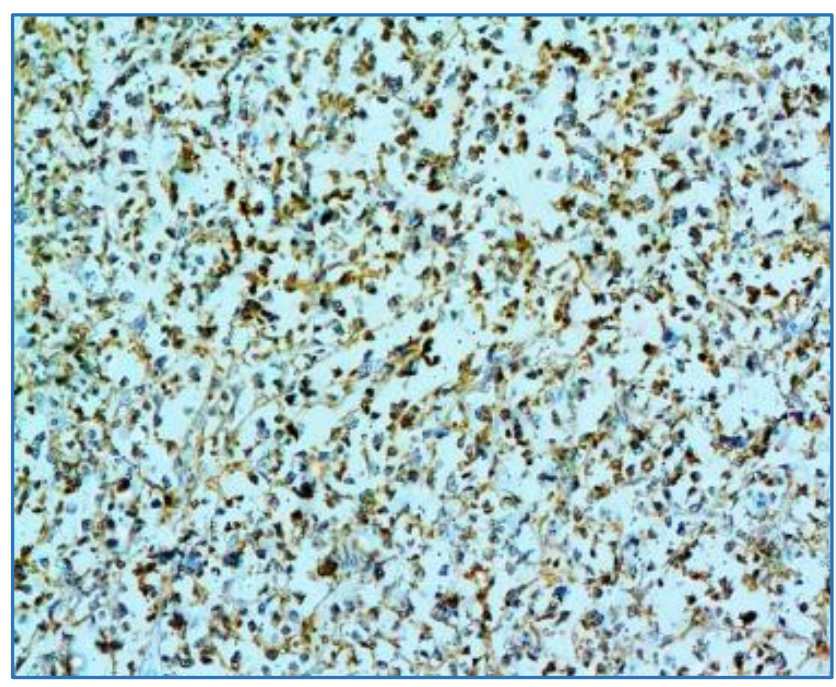

Figure 6. Non-Hodgkin's Lymphoma - IHC - CD20 (x 200)

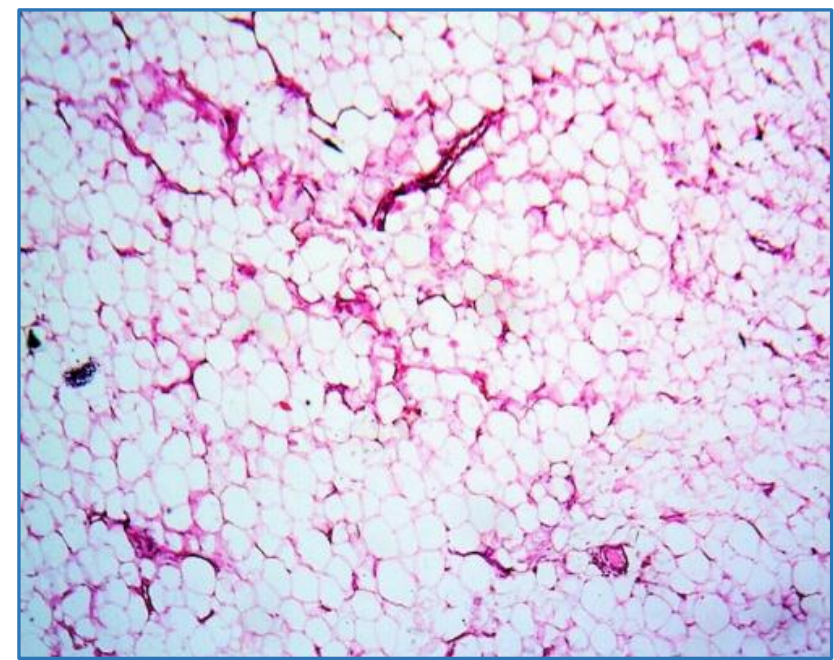

Figure 7. Lipomatous Polyp (H \& E X 40) 


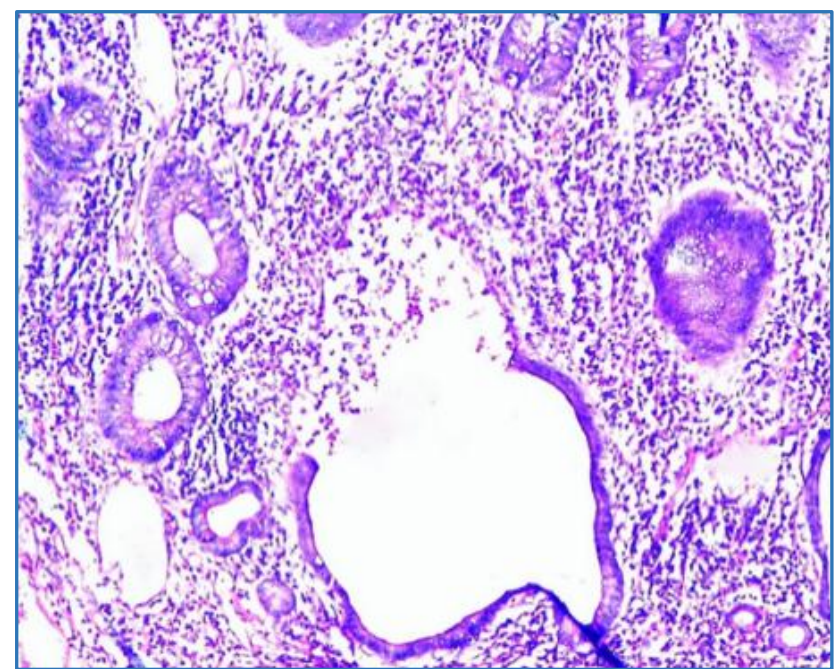

Figure 8. Juvenile Polyp (H\& Ex100)

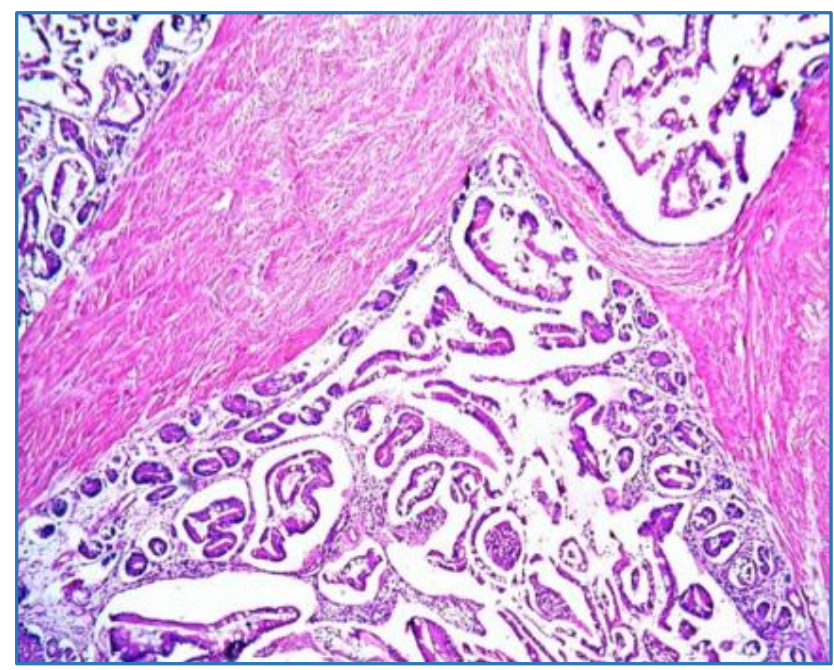

Figure 9. Peutz-Jegher Polyp: Glands with Arborizing Pattern of Smooth Muscle (H \& E x40)

\section{DISCUSSION}

160 cases of intestinal polyps were studied during period of 2 years. Among them 126 were neoplastic and 34 were nonneoplastic.

\section{Age}

Majority of cases of neoplastic polyps were in older age group (51 and above), while majority of non-neoplastic polyps were in younger age group ( $<30$ Yrs.). The age group of adenomatous polyps ranged from $10-19$ yrs. to 80 yrs. with maximum number of cases in age group 50 and above. This was comparable with the study conducted by Arnold et al. ${ }^{5}$ This indicates that the risk factor for development of colonic adenomatous polyps increases as age advances. According to Asia Pacific colorectal cancer working group, screening for colorectal cancer should be started at the age of 50 yrs. ${ }^{6}$ In study conducted by Jayadevan et al, there was a significant increase in incidence of polyps at age $40 .{ }^{7}$ According to this study, they proposed that screening colonoscopy should be started at age of 40 yrs. Among the non-neoplastic polyps, juvenile polyps constituted majority with majority of cases occurring in first decade. This was comparable with Irfan et al and Durno study. 8,9
Sex

In our study, adenomatous polyps showed male preponderance. Juvenile polyps also showed a male preponderance with maximum number of cases in the first decade. This was comparable with Irfan et al and Durno study. ${ }^{8,9}$ In our study, in both males and females the incidence of adenomatous polyps increased with age. But in an autopsy study conducted by Bombi, prevalence of adenomas increased with age and also according to sex. This increase in incidence with age was seen in men older than 60 yrs. In this study, actually the incidence was decreased in postmenopausal women. This may be due to the hormonal influence in pathogenesis of intestinal epithelial neoplasms. ${ }^{10}$

\section{Clinical Features}

Most frequent presenting complaint was bleeding per rectum.

\section{Site}

In our study, large intestine was the commonest site for the neoplastic polyps. This was in concordance with study conducted by Gurung et al and Rahat et al.11,12 In studies conducted by Gurung et al $83.6 \%$ of polyps were in large intestine and in studies conducted by Rahat et al $93 \%$ of polyps were in large intestine.

In this study, all the adenomatous polyps were in large intestine (100\%). Adenomatous polyps displayed left-sided predominance. These findings were in agreement with Konishi and Morson study, although number of cases in rectum was higher. ${ }^{13}$ Distal predominance of adenomatous polyps (Region where most colon cancers arise) supports the adenomacarcinoma hypothesis. In studies conducted by Eshgi et al, there is increasing right-sided prevalence of the adenomatous polyp with age. ${ }^{14}$ So they suggested that screening of proximal bowel is important in older patients. In our study also, majority of adenomatous polyps in right-sided colon were in older age group. Majority of the juvenile polyps were in the rectum, which was the same as in previous studies. ${ }^{8,9}$

\section{Size}

In our study among larger polyps, majority were neoplastic, while only few cases were non-neoplastic. According to Atkin et al, polyps of size $1 \mathrm{~cm}$ or more have more chance of subsequent malignancy, while polyps of size less than $1 \mathrm{~cm}$ does not have chances to become malignant. 15 In our study, larger adenomas were frequent in rectosigmoid colon. This was in concordance with an autopsy study conducted by Bombi. ${ }^{10}$ In this study, polyps $>1 \mathrm{~cm}$ size was seen only in rectosigmoid colon. In our study, adenomatous polyps in women were of larger size $(>=1 \mathrm{~cm})$ compared to those in men. The same finding was seen in studies conducted by Atkin et al. In studies conducted by Gentian et al, most of the intestinal polyps including adenomatous polyps were of size less than or equal to $1 \mathrm{~cm}$. But the risk of high-grade dysplasia was more in tumours more than $1 \mathrm{~cm} .16$

\section{Histomorphologic Types of Polyps}

In our study, adenomatous polyps represent $63.76 \%$ of all polyps studied. This was comparable with the study conducted by Eshghi et al and Geramizadeh B et al. ${ }^{14,17}$ While in study conducted by Deepa et al, juvenile polyps constituted the majority. ${ }^{18}$ In this study, majority of patient's age ranged from $1-17$ yrs. This may be the reason why juvenile polyps 
constituted the majority case. In study conducted by Irfan et al also, juvenile polyps constituted $67 \%$ of total polyps. According to study conducted by Cannon-Albright et al, incidence of adenomatous polyps was $12 \%$ in a study of unselected patients. ${ }^{2}$ In another autopsy study, incidence was $30 \% .^{3}$

Among mesenchymal polyps, lipomatous polyp was the most common followed by inflammatory fibroid polyp. Incidence of colonic lipomas varies between $0.2 \%$ and $4.4 \%$. In studies conducted in Spain, lipomatous polyp constituted for $4.1 \%$ of all polyps studied which was comparable to our study (5.63\%). ${ }^{10}$ While in studies conducted by Rahat and Sadique, lipomatous polyp constituted only $0.66 \%$ of the polyps studied. ${ }^{12}$ Inflammatory fibroid polyp usually occurs in the small intestine and can occur at any age. ${ }^{19}$ Majority of lesion show spindle cells, richly vascularised stroma and inflammatory cells. ${ }^{20}$ In our study also majority of the cases were in small intestine. In previous studies of gastrointestinal lymphomas, MALT category was the most common type. In lymphomas presenting as polyps, usual histology was that of mantle cell lymphoma. ${ }^{21,22}$ In our study, Mucosa Associated Lymphoid Tissue (MALT) category was the common type.

In our study, the most common non-neoplastic polyps of the colon were the juvenile polyp. This was in concordance with the study conducted by Irfan et al. ${ }^{8}$ In studies conducted by Hiroshi et al, juvenile polyps occurred frequently in first decade with male predominance. They were found frequently in rectum and sigmoid colon. ${ }^{23}$ Our study also showed similar finding. But in study conducted by Arnold et al, hyperplastic polyps accounted for majority of non-neoplastic polyps. ${ }^{5}$ There were four cases of Peutz-Jeghers polyps (25\%) with 2 cases each in the small intestine and large intestine. According to study conducted by McGarrity et al, solitary Peutz-Jeghers polyps are rare and are associated with Peutz-Jeghers syndrome. ${ }^{24}$

\section{CONCLUSION}

This study summarises various types of intestinal polyps. Adenomatous polyp presented the majority type. Thus, early diagnosis of adenomatous polyps helps in the long-term prevention of colorectal cancer. Adenomatous polyps showed an increase in incidence in older age group in both males and females. This shows that risk factor for development of adenomatous polyps and hence colorectal malignancy increases as age advances. So screening for colorectal cancer should be started at age of 50 yrs. or even earlier. All the adenomatous polyps were in large intestine with preference for sigmoid colon and rectum. Distal predominance of adenomatous polyps support adenoma-carcinoma hypothesis. Majority of adenomatous polyps in right-sided colon were in older age group. So screening of proximal bowel in addition is important in older patients. Among larger polyps $(>1 \mathrm{~cm})$, majority were neoplastic. Adenomas with increased size ( $>=1$ $\mathrm{cm}$ ) have increased incidence of malignancy. The main aim of screening is to detect early lesions. In younger children, most common polyps of the colon were juvenile polyp which is a non-neoplastic polyp.

The main limitation of this study is that sample sizes in different subgroups are small and family history and diet history were not studied in detail. The main strength is that from a single institution, different types of polyps were studied. There is a need for developing a registry for all cases of polyps. This will help in estimating the true incidence of polypoid lesions in our population. This can form basis for further study.

\section{REFERENCES}

1. Hamilton SR, Aaltonen LA. World Health Organization. Classification of tumors. Pathology and genetics of tumors of the digestive system. IARC Press: Lyon 2000.

2. Cannon-Albright LA, Bishop T, Samowitz W, et al. Colonic polyps in a unselected population: prevalence, characteristics and associations. Am J Gastrointestinal 1994;89(6):827-31.

3. Clark JC, Collan Y, Eide TJ, et al. Prevalence of polyps in an autopsy series from areas with varying incidence of large bowel cancer. Int J Cancer 1985;36(2):179-86.

4. Haggitt RC, Glotzbach RE, Soffer EE, et al. Prognostic factors in colorectal carcinomas arising in adenomas: implications for lesions removed by endoscopic polypectomy. Gastroenterology 1985;89(2):328-36.

5. Markowitz AJ, Winawer SJ. Management of colorectal polyps. CA Cancer J Clin 1997;47(2):93-112.

6. Sung JJ, Lau JY, Young GP, et al. Asia pacific consensus recommendations for colorectal cancer screening. Gut 2008;57(8):1166-76.

7. Jayadevan R, Anithadevi TS, Venugopalan RP, et al. Prevalence of colorectal polyps: a retrospective study to determine the cut-off age for screening. Gastroenterol Pancreatol Liver Disord 2016;3(2):1-5.

8. Ahmad I, Khan AA, Alam A, et al. A study of colorectal polyps. JCPSP 2006;16(5):364-7.

9. Durno CA. Colonic polyps in children and adolescents. Can J Gastroenterol 2007;21(4):233-9.

10. Bombi JA. Polyps of the colon in Barcelona, Spain. An Autopsy study. Cancer 1988;61(7):1472-6.

11. Gurung $P$, Hirachand $S$, Pradhanang $S$, et al. A histopathological study of gastrointestinal polyps in tertiary care hospital, Nepal. Journal of Institute of Medicine 2014;36(1):64-8.

12. Rahat N, Sadiq S. Morphological study of the polypoid lesions of the gastrointestinal tract. Pak J Med Sci 2005;21(3):318-24.

13. Konishi F, Morson BC. Pathology of colorectal adenomas: a colonoscopic survey. J Clin pathol 1982;35(8):830-41.

14. Eshghi MJ, Fatemi R, Hashemy A, et al. A retrospective study of patients with colorectal polyps. Gastroenterology and Hepatology from Bed to Bench 2011;4(1):17-22.

15. Atkin WS, Morson BC, Cuzick J. Long-term risk of colorectal cancer after excision of rectosigmoid adenomas. N Engl J Med 1992;326(10):658-62.

16. Gentiana C, Altin C, Arben B, et al. Histopathological characteristics of colon polyps-a population-based study in Tirana, Albania. J Gastrointest Dig Syst 2015;5:271.

17. Geramizadeh B, Keshtkar-Jahromi M. Pathology of colorectal polyps: a study from south of Iran. Annals of Colorectal Research 2013;1(2):60-2.

18. Kunjumon DT, Glaxon JA, Pushpalatha PK. A histopathological study of 23 cases of benign epithelial polyps of intestine. IJBR 2014;5(2). 
19. Shimer GR, Helwig EB. Inflammatory fibroid polyps of the intestine. Am J Cin pathol 1984;81(6):708-14.

20. Santos GC, Alves VA, Wakamatsu A, et al. Inflammatory fibroid polyp: an immunohistochemical study. Arq Gastroenterol 2004;41(2):104-7.

21. Ghimire $\mathrm{P}$, Guang-Yao $\mathrm{Wu}, \mathrm{Zhu}$ L. Primary gastrointestinal lymphoma. World J Gastroenterol 2011;17(6):697-707.

22. Yatabe $Y$, Nakamura $S$, Kobayashi $T$, et al. Multiple polypoid lesions of primary mucosa associated lymphoid tissue lymphoma of colon. Histopathology 1998;32(2):116-25.
23. Yamagiwa $H$, Ishihara $A$, Matsuzaki 0 , et al. Clinicpathological study of juvenile polyp. Gastroenterologia japonica 1979;14(5):425-31.

24. McGarrity TJ, Kulin HE, Zaino RJ. Peutz-Jeghers syndrome. Am J Gastroenterology 2000;95(3):596-604. 